\title{
SIRT1 activation inhibits hyperglycemia-induced apoptosis by reducing oxidative stress and mitochondrial dysfunction in human endothelial cells
}

\author{
SHENGQIANG WANG, JIAN WANG, AIRONG ZHAO and JIGANG LI \\ Department of Cardiology, The 148th Central Hospital of The People's Liberation Army, Zibo, Shandong 255300, P.R. China
}

Received November 9, 2015; Accepted December 8, 2016

DOI: $10.3892 / \mathrm{mmr} .2017 .7027$

\begin{abstract}
Sustained hyperglycemic stimulation of vascular cells is involved in the pathogenesis of diabetes mellitus-induced cardiovascular complications. Silent information regulator T1 (SIRT1), a mammalian sirtuin, has been previously recognized to protect endothelial cells against hyperglycemia-induced oxidative stress. In the present study, human umbilical vein endothelial cells (HUV-EC-C) were treated with D-glucose, and the levels of oxidative stress, mitochondrial dysfunction, the rate of apoptosis and SIRT1 activity were measured. The effect of manipulated SIRT1 activity on hyperglycemia-induced oxidative stress, mitochondrial dysfunction and apoptosis was then assessed using the SIRT1 activator, resveratrol (RSV), and the SIRT1 inhibitor, sirtinol. The present study confirmed that hyperglycemia promotes oxidative stress and mitochondrial dysfunction in HUV-EC-C cells. The accumulation of reactive oxygen species, the swelling of mitochondria, the ratio of adenosine 5'-diphosphate to adenosine 5'-triphosphate and localized mitochondrial superoxide levels were all increased following D-glucose treatment, whereas the mitochondrial membrane potential was significantly reduced by $>50 \mathrm{mg} / \mathrm{ml} \mathrm{D}$-glucose treatment. In addition, hyperglycemia was confirmed to induce apoptosis in HUV-EC-C cells. Furthermore, the results confirmed the prevention and aggravation of hyperglycemia-induced apoptosis by RSV treatment and sirtinol treatment, via the amelioration and enhancement of oxidative stress and mitochondrial dysfunction in HUV-EC-C cells, respectively. In conclusion, the present study revealed that hyperglycemia promotes oxidative stress, mitochondrial dysfunction and apoptosis in HUV-EC-C cells, and manipulation of SIRT1 activity regulated hyperglycemia-induced mitochondrial dysfunction and apoptosis in HUV-EC-C cells. The data revealed the protective effect of SIRT1 against
\end{abstract}

Correspondence to: Dr Shengqiang Wang, Department of Cardiology, The 148th Central Hospital of The People's Liberation Army, 20 Zhanbei Road, Zibo, Shandong 255300, P.R. China E-mail: shengq_wang@163.com

Key words: sirtuin 1 activation, high glucose, oxidative stress, mitochondrial dysfunction, endothelial cells hyperglycemia-induced apoptosis via the alleviation of mitochondrial dysfunction and oxidative stress.

\section{Introduction}

Accumulating evidence suggests that oxidative stress may contribute to diabetes mellitus (DM)-associated cardiovascular complications. Hyperglycemia and elevated levels of free fatty acids and lipids promote oxidative stress in DM, which results in cardiovascular damage (1). Hyperglycemia, in particular, has been demonstrated to induce inflammation and apoptosis in retinal, cardiovascular and kidney cells; all of which have been implicated in DM-associated complications (2-4). DM-associated oxidative stress is the result of high levels of reactive oxygen species (ROS) (5-7). Increased glucose levels promote ROS production via the following two major mechanisms: i) The action of nicotinamide adenine dinucleotide phosphate (NADPH) oxidase located on the plasma membrane, and ii) dysfunction of the mitochondrial electron transport chain (8-10). ROS activates multiple biochemical pathways, including the formation of advanced glycation end products $(11,12)$, protein kinase $C$ activation $(13,14)$ and the hexosamine pathway $(15)$, which propagate further ROS production and increases oxidative stress. Therefore, prevention of ROS production through inhibiting mitochondrial dysfunction has been proposed as an alternative approach to conventional antioxidant therapies to treat diabetes and vascular complications (16).

Hyperglycemia-induced apoptosis and inflammatory responses have been recognized as cardiovascular complications of DM (4), and multiple signaling pathways have been implicated in hyperglycemia-induced apoptosis of cardiovascular cells $(3,17,18)$. By contrast, high glucose levels activate cellular defenses against oxidative stress. Nuclear factor (erythroid-derived 2)-like-2 is a redox sensitive transcription factor that has been implicated in the anti-oxidative stress response to hyperglycemia (19). Neuregulin protects human umbilical vein endothelial cells against hyperglycemia-induced apoptosis via activation of the cluster of differentiation 98 heavy chain through the mitogen-activated protein kinase pathway (20). In addition, upregulated angiotensin (1-7) preserves endothelial function by reducing oxidative stress in DM (21), and glucagon-like peptide-1 suppresses hyperglycemia-induced oxidative stress in patients with DM (22). Therefore, investigating the molecular pathways underlying 
cellular defenses against hyperglycemia-induced oxidative stress is vital.

Silent information regulator T1 (SIRT1), also known as the nicotinamide adenine dinucleotide-dependent deacetylase sirtuin-1, is a member of a family of highly conserved proteins that regulate a variety of metabolic functions, particularly glucose homeostasis in mammals (23). SIRT1 is involved in alleviating mitochondrial dysfunction and oxidative stress (24). In the present study, the promotion of mitochondrial dysfunction and apoptosis by hyperglycemia was examined in human umbilical vein endothelial (HUV-EC-C) cells. SIRT1 activity was manipulated using the SIRT1 activator resveratrol (RSV) and the SIRT1 inhibitor, sirtinol. The effect of increased and decreased SIRT1 activity on hyperglycemia-induced mitochondrial dysfunction and apoptosis in HUV-EC-C cells was then examined. The data revealed the protective effects of SIRT1 against hyperglycemia-induced apoptosis, which functions through the alleviation of mitochondrial dysfunction and oxidative stress.

\section{Materials and methods}

Cell culture and treatment. The HUV-EC-C human umbilical vein endothelial cell line was purchased from the American Type Culture Collection (Manassas, VA, USA) and propagated in Kaighn's modification of Ham's F-12 medium (Sigma-Aldrich; Merck KGaA, Darmstadt, Germany) supplemented with $10 \%$ fetal bovine serum (FBS; Gibco; Thermo Fisher Scientific, Inc., Waltham, MA, USA) and $1 \mathrm{X}$ penicillin/streptomycin (100 units $/ \mathrm{ml}$ penicillin and $100 \mu \mathrm{g} / \mathrm{ml}$ streptomycin; Sigma-Aldrich; Merck KGaA) at $37^{\circ} \mathrm{C}$ and $5 \% \mathrm{CO}_{2}$. For the D-glucose (Sigma-Aldrich; Merck KGaA) treatment, HUV-EC-C cells (at $>85 \%$ confluence) were treated with 5 (as a control), 15, 50 or $150 \mathrm{mg} / \mathrm{ml}$ D-glucose for $0,1,2,4,6,8,16$, 24,32 or $48 \mathrm{~h}$ at $37^{\circ} \mathrm{C}$. Control cells were treated with $5 \mathrm{mg} / \mathrm{ml}$ $\mathrm{D}$-glucose as this was required for HUV-EC-C cell culture. The SIRT1 activator (RSV; $5 \mu \mathrm{M}$ ) and the SIRT1 inhibitor (sirtinol; $10 \mu \mathrm{M}$ ), were obtained from Sigma-Aldrich (Merck KGaA), and were used to regulate SIRT1 activity in D-glucose-treated HUV-EC-C cells ( $>85 \%$ confluence), and were incubated with cells for $8,16,24$ or $48 \mathrm{~h}$ at $37^{\circ} \mathrm{C}$ and $5 \% \mathrm{CO}_{2}$.

Apoptosis assay via annexin $V$-fluorescein isothiocyanate (FITC)/propidium iodide (PI) staining. Following D-glucose treatment, apoptosis was examined in HUV-EC-C cells using an annexin V-FITC/PI staining kit (Thermo Fisher Scientific, Inc.) according to the manufacturer's instructions. Briefly, treated HUV-EC-C cells were harvested, re-suspended in binding buffer $\left(10^{6}\right.$ cells $\left./ \mathrm{ml}\right)$ and incubated with a mixture of $5 \mu \mathrm{l}$ annexin V-FITC and $10 \mu \mathrm{l}$ PI for $15 \mathrm{~min}$ in the dark at room temperature. Stained cells were visualized with a live cell imaging system (Olympus Corporation, Tokyo, Japan) and photographed using a velocity demo imaging system (PerkinElmer, Waltham, MA, USA). The number of apoptotic cells was expressed as the percentage of annexin $\mathrm{V}(+) / \mathrm{PI}(-)$ cells out of the total number cells.

Nuclear/cytosol protein fractionation, isolation and western blotting assay. A Nuclear/Cytosol Fractionation kit (BioVision, Inc., Milpitas, CA, USA) was used to isolate the nuclear and cytosol protein fractions in HUV-EC-C cells. In brief, post-treatment, HUV-EC-C cells $\left(\sim 5 \times 10^{6}\right)$ were detached via centrifugation for $5 \mathrm{~min}$ at $600 \mathrm{x}$ g at $4^{\circ} \mathrm{C}$ and were washed three times with ice-cold $1 \mathrm{X}$ phosphate buffered saline. The HUV-EC-C cells $\left(\sim 5 \times 10^{6}\right)$ were carefully resuspended in $500 \mu 1$ ice-cold, $1 \mathrm{X}$ cytosol extraction buffer [containing dithiothreitol (DTT)/protease inhibitors] by pipetting up and down. Following centrifugation at $800 \mathrm{x}$ g for $10 \mathrm{~min}$ at $4^{\circ} \mathrm{C}$, the supernatant (cytoplasmic fraction) was pipetted and stored at $-80^{\circ} \mathrm{C}$ for future use. The nuclear pellet was carefully resuspended in $100 \mu 1$ ice-cold $1 \mathrm{X}$ nuclear extraction buffer (containing DTT/protease inhibitors) by pipetting up and down, before samples were centrifuged at 14,000 $\mathrm{x}$ g for $30 \mathrm{~min}$ at $4^{\circ} \mathrm{C}$. The supernatant (nuclear protein extract) was carefully transferred to another tube, and stored at $-80^{\circ} \mathrm{C}$ for future use.

For the western blotting assay, protein samples $(15 \mu \mathrm{g}$ per lane) were successively subjected to electrophoresis on $12 \%$ SDS-PAGE gels and transferred to nitrocellulose membranes (EMD Millipore, Billerica, MA, USA). Membranes were blocked with $2 \% \mathrm{FBS}$ at $4^{\circ} \mathrm{C}$ overnight, and incubated with primary rabbit polyclonal antibodies against cytochrome $\mathrm{c}$ (cat. no. ab90529; 1:500; Abcam, Cambridge, UK), caspase 3 (cat. no. ab44976; 1:600; Abcam), poly (ADP-ribose) polymerase-1 (PARP; cat. no. ab32071; 1:400; Abcam), SIRT1 (cat. no. S5447; Sigma-Aldrich; Merck KGaA) or $\beta$-actin [cat. no. ab95437; diluted with 5\% bovine serum albumin (Gibco; Thermo Fisher Scientific, Inc.) to 1:1,000; Abcam] for $2 \mathrm{~h}$ at $37^{\circ} \mathrm{C}$. The membranes were then incubated with horseradish peroxidase-conjugated goat anti-rabbit immunoglobulin G secondary antibody (cat. no. HAF008; 1:1,000; $\mathrm{R} \& \mathrm{D}$ Systems, Inc., Minneapolis, MN, USA) for $2 \mathrm{~h}$ at $37^{\circ} \mathrm{C}$. ECL $^{\text {TM }}$ Western Blotting Detection Reagents (GE Healthcare Life Sciences, Little Chalfont, UK) were used to detect the target protein bands.

Measurement of intracellular ROS and mitochondrial superoxide. Intracellular ROS levels in $\sim 2 \times 10^{6}$ cells were monitored using the fluorescent probe 2', $7^{\prime}$-dichlorofluorescin (DCFH) diacetate (5 $\mu \mathrm{mol} / 1$; Sigma-Aldrich; Merck KGaA), which was oxidized to the highly fluorescent compound DCF. DCF-positive cells were visualized under a live cell imaging system (Olympus Corporation) with excitation measured at $485 \mathrm{~nm}$ and emission at $530 \mathrm{~nm}$. In order to confirm that D-glucose treatment generates ROS, the conversion of dihydroethidium (DHE) to ethidium by oxidation was measured, and the ratio of DHE/ethidium was determined. DHE excitation was measured at $355 \mathrm{~nm}$ and emission at $430 \mathrm{~nm}$, while ethidium excitation was measured at $518 \mathrm{~nm}$ and emission at $605 \mathrm{~nm}$. Mitochondrial superoxide was quantified with MitoSOX $^{\text {TM }}$ Red (Invitrogen; Thermo Fisher Scientific, Inc.), which is live-cell-permeable and indicates mitochondrial localized superoxide. HUV-EC-C cells (at $>85 \%$ confluence) were incubated with $5 \mu \mathrm{M}$ MitoSOX ${ }^{\mathrm{TM}}$ Red at $37^{\circ} \mathrm{C}$ for $20 \mathrm{~min}$ according to the manufacturer's protocol. The MitoSOX ${ }^{\mathrm{TM}}$ Red fluorescence was detected with an excitation at $510 \mathrm{~nm}$ and emission at $580 \mathrm{~nm}$ (FACSCanto flow cytometer). Data were processed by using CellQuest Pro software (version, 5.1; BD Biosciences, Franklin Lakes, NJ, USA). The data were obtained from five independent images taken from each group, and each experiment was repeated in triplicate. 
Measurement of mitochondrial size and mitochondrial membrane potential $(M M P)$. HUV-EC-C cells $\left(\sim 2 \times 10^{6}\right)$ were stained with $20 \mathrm{nM}$ MitoTracker Orange CMTMRos (Thermo Fisher Scientific, Inc.) at $25^{\circ} \mathrm{C}$ for $2 \mathrm{~h}$, and mitochondrial size was measured in four fields per group using an Olympus FV500 confocal fluorescence microscope (Olympus Corporation) at $540 \mathrm{~nm}$ excitation. A JC-1 Mitochondrial Membrane Potential assay kit (Cayman Chemical Company, Ann Arbor, MI, USA) was used to measure the MMP of treated HUV-EC-C cells, according to manufacturer's instructions. Briefly, the treated cells $\left(\sim 2 \times 10^{6}\right)$ were incubated with JC-1 staining solution $(5 \mu \mathrm{g} / \mathrm{ml})$ for $20 \mathrm{~min}$ at $37^{\circ} \mathrm{C}$. The fluorescence intensity of mitochondrial JC-1 monomers (514 $\mathrm{nm}$ excitation, $529 \mathrm{~nm}$ emission) and aggregates (585 nm excitation, $590 \mathrm{~nm}$ emission) were detected using a live cell imaging system (Olympus Corporation).

Measurement of adenosine 5'-diphosphate (ADP):adenosine trisphosphate (ATP) ratios. ATP and ADP levels were measured using an ADP Colorimetric/Fluorometric assay kit (BioVision, Inc., Milpitas, CA, USA) and a luminescence plate reader (PerkinElmer, Inc.). Following D-glucose treatment, HUV-EC-C cells cultured in 12 -well plates ( 2 x105 cells/well) were lysed using the kit's nucleotide-releasing reagent and transferred to 96-well white-walled plates according to the manufacturer's instructions. ATP was measured in the sample, then ADP was converted to ATP and the measurement was repeated to permit the calculation of the ADP:ATP ratio.

RNA isolation and reverse transcription-quantitative polymerase chain reaction ( $R T-q P C R)$. Total cellular RNA from HUV-EC-C cells $\left(\sim 5 \times 10^{6}\right)$ was isolated using an mRNA Isolation and Purification kit (Clontech Laboratories, Inc., Mountain View, CA, USA) containing RNasin ${ }^{\circledR}$ Plus RNase Inhibitor (Promega Corporation, Madison, WI, USA). Reverse transcription of total RNA $(2 \mathrm{~mol} / \mu \mathrm{l})$ and $\mathrm{qPCR}$ was performed with the One Step SYBR PrimeScript Plus RT-PCR kit (Perfect Real Time; Takara Bio, Otsu, Japan). The reaction mix (20 $\mu \mathrm{l})$ contained the following: 2X One Step RT-PCR Buffer III (10 $\mu \mathrm{l})$; TaKaRa Ex Taq HS (5 U/ $\mu 1 ; 0.4 \mu \mathrm{l}$ ); PrimeScript RT Enzyme Mix II $(0.4 \mu \mathrm{l})$; forward/reverse primer (10 $\mu \mathrm{M}$; $0.4 \mu \mathrm{l}$ each); probe $(0.8 \mu \mathrm{l})$; target RNA $(2 \mu \mathrm{l})$; and RNase Free $\mathrm{dH}_{2} \mathrm{O}(5.6 \mu \mathrm{l})$. The PCR reaction was performed as follows: Stage 1 for reverse transcription reaction, $42^{\circ} \mathrm{C}$ for $5 \mathrm{~min}$ and $95^{\circ} \mathrm{C}$ for $10 \mathrm{sec}$ for 1 cycle; Stage 2 for PCR reaction, $95^{\circ} \mathrm{C}$ for $5 \mathrm{sec}$ and $60^{\circ} \mathrm{C}$ for $20 \mathrm{sec}$ for 40 cycles. The following primers were obtained from Sangon Biotech Co., Ltd. (Shanghai, China): SIRT1, 5'-GAA TACCTGACTTCAGGTCA-3' (forward) and 5'-GAATACCTG ACTTCAGGTCA-3' (reverse); $\beta$-actin, 5'-TGTCCACCTTCC AGCAGATGT-3' (forward) and 5'-AGCTCAGTAACAGTC CGCCTAGA-3' (reverse). The experiment was repeated three times. Relative quantification was determined using the $2-\Delta \Delta \mathrm{Cq}$ method with $\beta$-actin as a reference gene (25).

SIRT1 activity assay. SIRT1 activity was measured using a SIRT1 Activity assay kit (Fluorometric; Abcam), according to the manufacturer's protocol. Cells $\left(\sim 2 \times 10^{6}\right)$ were lysed using Pierce Universal Nuclease (Thermo Fisher Scientific, Inc.). Freshly lyzed cellular solution was immunoprecipitated using a Dynabeads ${ }^{\circledR}$ Co-Immunoprecipitation kit (Thermo Fisher Scientific, Inc.) and an anti-SIRT1 antibody (cat. no. S5447;
Sigma-Aldrich; Merck KGaA). Subsequently, fluorosubstrate peptide solution and protein A agarose beads were simultaneously added into the reaction mix, and the NAD-dependent deacetylase activity was measured based on fluorescence intensity at $2 \mathrm{~min}$ intervals at excitation/emission $=350 / 460 \mathrm{~nm}$ (BX-URA2; Olympus Corporation) and was presented as the percentage of the control group.

Statistical analysis. SPSS statistical software (version, 16.0; SPSS, Inc., Chicago, IL, USA) was utilized to analyze statistical differences. Normally distributed quantitative data was expressed as the mean \pm standard error, while data that was not normally distributed was logarithmically transformed for further analysis. The Student's t-test or two-way analysis of variance and Dunnett's post-hoc test were used to determine significant differences between two groups and among multiple groups, respectively. $\mathrm{P}<0.05$ was considered to indicate a statistically significant difference.

\section{Results}

Hyperglycemia induces apoptosis in human umbilical vein endothelial HUV-EC-C cells. To investigate the influence of hyperglycemia on the viability of human endothelial cells, HUV-EC-C cells were treated with a range of D-glucose concentrations for different durations, in order to evaluate hyperglycemia-induced apoptosis. Treatment with 50 and $150 \mathrm{mg} / \mathrm{ml} \mathrm{D}$-glucose significantly increased the percentage of apoptotic HUV-EC-C cells when compared with control cells $(50 \mathrm{mg} / \mathrm{ml}, \mathrm{P}<0.01$ and $\mathrm{P}<0.01$ at 24 and $48 \mathrm{~h}$, respectively; $150 \mathrm{mg} / \mathrm{ml}, \mathrm{P}<0.001$ and $\mathrm{P}<0.001$ at 24 and $48 \mathrm{~h}$, respectively; Fig. 1A). The induction of apoptosis was dose-dependent, with significantly increased apoptosis levels in $150 \mathrm{mg} / \mathrm{ml} \mathrm{D}$-glucose treated cells when compared with $50 \mathrm{mg} / \mathrm{ml}$ D-glucose-treated cells $(\mathrm{P}<0.05$; Fig. 1A). Western blot analysis revealed a notable increase in apoptosis markers, including released cytochrome $\mathrm{C}$, cleaved caspase 3 and lysed PARP in $150 \mathrm{mg} / \mathrm{ml} \mathrm{D}$-glucose-treated cells following $24 \mathrm{~h}$ treatment when compared with the controls (Fig. 1B). The release of cytochrome $\mathrm{C}$ from mitochondria was significantly upregulated by 50 or $150 \mathrm{mg} / \mathrm{ml} \mathrm{D}$-glucose treatment when compared with control cells $(\mathrm{P}<0.05$ and $\mathrm{P}<0.01$, respectively; Fig. 1C). This effect was also dose-dependent, with increased cytochrome $\mathrm{C}$ levels in $150 \mathrm{mg} / \mathrm{ml} \mathrm{D}$-glucose treated cells compared with $50 \mathrm{mg} / \mathrm{ml} \mathrm{D}$-glucose treated cells $(\mathrm{P}<0.05$; Fig. 1C). Similar increases in expression were demonstrated in D-glucose treated cells compared with controls for cleaved caspase 3 (50 mg/ml, P<0.05; $150 \mathrm{mg} / \mathrm{ml}, \mathrm{P}<0.01$; Fig. 1D) and lysed PARP $(50 \mathrm{mg} / \mathrm{ml}, \mathrm{P}<0.01 ; 150 \mathrm{mg} / \mathrm{ml}, \mathrm{P}<0.001$; Fig. 1D). The effect of D-glucose on cleaved caspase 3 and lysed PARP levels were dose-dependent, with significantly greater increases in $150 \mathrm{mg} / \mathrm{ml}$-treated cells when compared with $50 \mathrm{mg} / \mathrm{ml}$-treated cells (cleaved caspase 3, $\mathrm{P}<0.05$; lysed PARP, P<0.05; Fig. 1D). Therefore, hyperglycemia was confirmed to induce apoptosis in HUV-EC-C cells.

Hyperglycemia promotes ROS accumulation in HUV-EC-C cells. Previous studies have demonstrated an association between oxidative stress and hyperglycemia-induced apoptosis in cardiac myocytes (26) and endothelial cells (27). Therefore, 

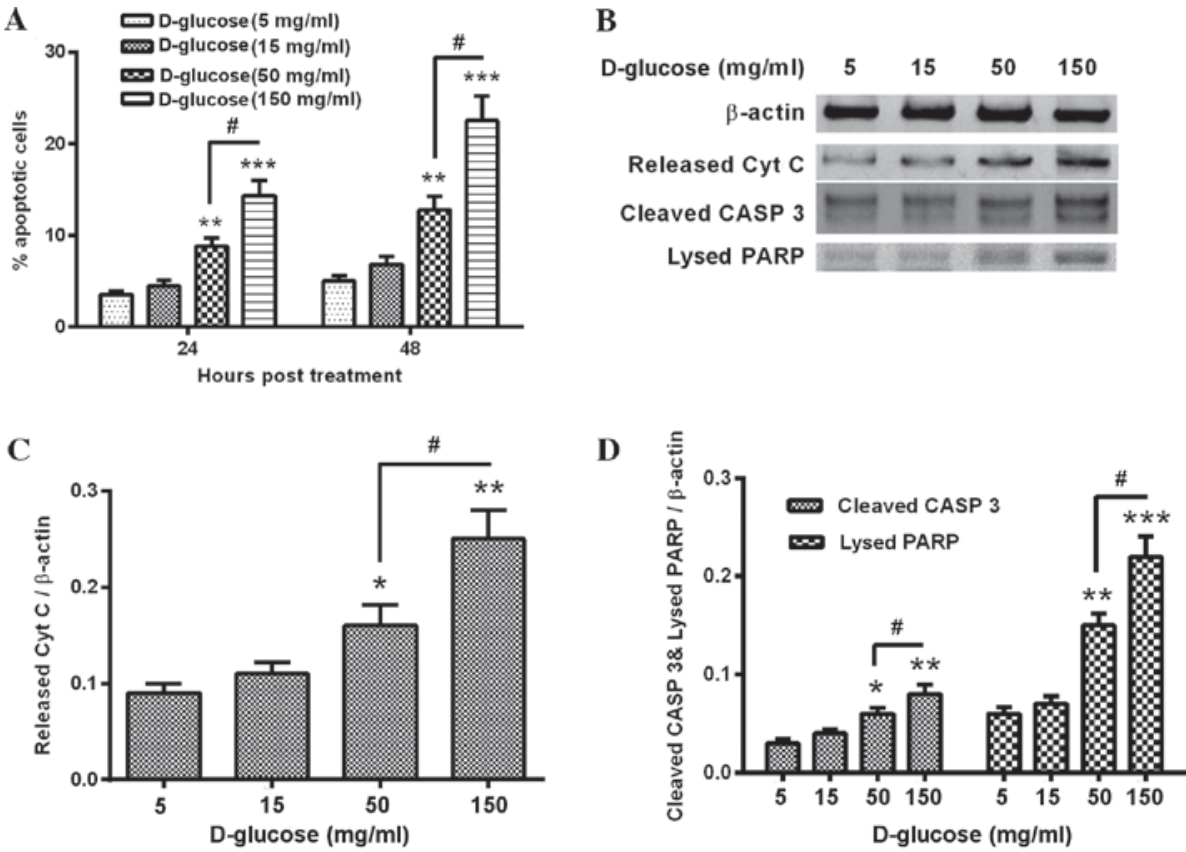

Figure 1. Effect of hyperglycemia on apoptosis in human endothelial HUV-EC-C cells. (A) Apoptosis rate in HUV-EC-C cells treated with varying concentrations of D-glucose for 24 and $48 \mathrm{~h}$. (B) Western blot analysis of Cyt C, cleaved CASP 3 and lysed PARP release in D-glucose-treated HUV-EC-C cells (C) Relative level of released Cyt C, (D) cleaved CASP3 and lysed PARP in D-glucose-treated HUV-EC-C cells. ${ }^{*} \mathrm{P}<0.05,{ }^{* * *} \mathrm{P}<0.01$ and ${ }^{* * * *} \mathrm{P}<0.001$ vs. the $5 \mathrm{mg} / \mathrm{ml} \mathrm{D}$-glucose control; " $\mathrm{P}<0.05$ as indicated. Cyt C, cytochrome C; CASP 3, caspase 3; PARP, poly(ADP-ribose) polymerase-1.
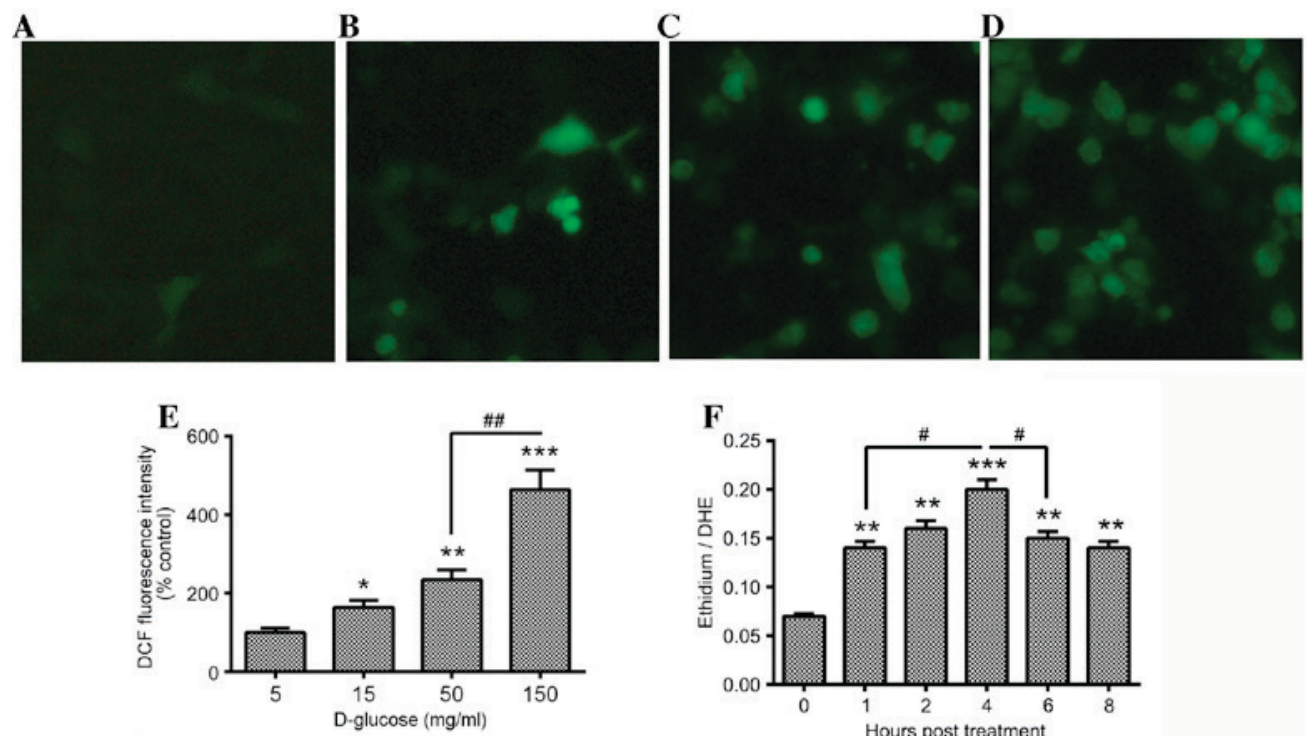

Figure 2. Hyperglycemia-induced accumulation of intracellular reactive oxygen species in HUV-EC-C cells. Representative images (magnification, x40) of DCF staining in HUV-EC-C cells treated with (A) 5 , (B) 15, (C) 50 or (D) $150 \mathrm{mg} / \mathrm{ml} \mathrm{D-glucose} \mathrm{(E).} \mathrm{Quantitative} \mathrm{analysis} \mathrm{of} \mathrm{DCF} \mathrm{fluorescence} \mathrm{intensity}$ in D-glucose-treated HUV-EC-C cells ( $\mathrm{P}<0.05,{ }^{* * *} \mathrm{P}<0.01$ and ${ }^{* * * *} \mathrm{P}<0.001 \mathrm{vs} .5 \mathrm{mg} / \mathrm{ml} \mathrm{D}$-glucose; ${ }^{\# \#} \mathrm{P}<0.01$ as indicated). (F) Ratio of ethidium to DHE in HUV-EC-C cells at $0-8 \mathrm{~h}$ following treatment with $50 \mathrm{mg} / \mathrm{ml}$ D-glucose $\left({ }^{*} \mathrm{P}<0.05,{ }^{* *} \mathrm{P}<0.01\right.$ and ${ }^{* * *} \mathrm{P}<0.001 \mathrm{vs} .0 \mathrm{~h} ;{ }^{*} \mathrm{P}<0.05$ as indicated). DCF, 2',7'-dichlorofluorescin; DHE, dihydroethidium.

the accumulation of ROS in D-glucose-treated HUV-EC-C cells was examined using DCFH, which oxidizes to form the highly fluorescent compound DCF. A small number of DCF-positive (green fluorescence) HUV-EC-C cells were present in the control group (Fig. 2A). However, there were significantly increased levels of DCF-positive cells in the 15 (Fig. 2B) 50 (Fig. 2C) and $150 \mathrm{mg} / \mathrm{ml}$ (Fig. 2D) D-glucose-treated groups when compared with the control cells $(\mathrm{P}<0.05, \mathrm{P}<0.01$ and $\mathrm{P}<0.001$, respectively; Fig. 2E). This effect was dose-dependent, with significantly increased levels of DCF-positive cells in the $150 \mathrm{mg} / \mathrm{ml}$ treatment group compared with the $50 \mathrm{mg} / \mathrm{ml}$ treated group ( $\mathrm{P}<0.01 ;$ Fig. $2 \mathrm{E})$. To determine the time-course of ROS production in the D-glucose-treated HUV-EC-C cells, the conversion of DHE to ethidium by oxidation was measured by assaying the ratio of DHE to ethidium using a fluorimeter. ROS generation increased in a dose-dependent manner in $50 \mathrm{mg} / \mathrm{ml} \mathrm{D-glucose-treated} \mathrm{HUV-EC-C} \mathrm{cells}$ from 1-8 h following treatment, with increased levels of ROS 
A

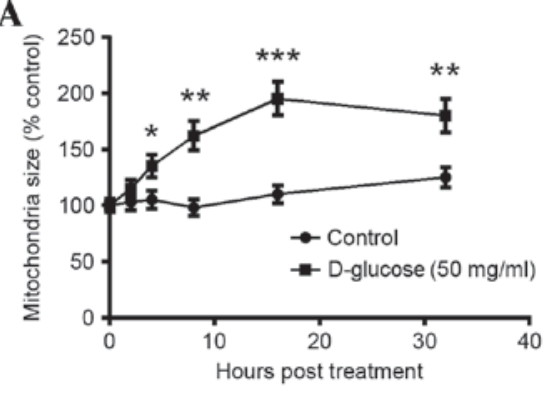

C

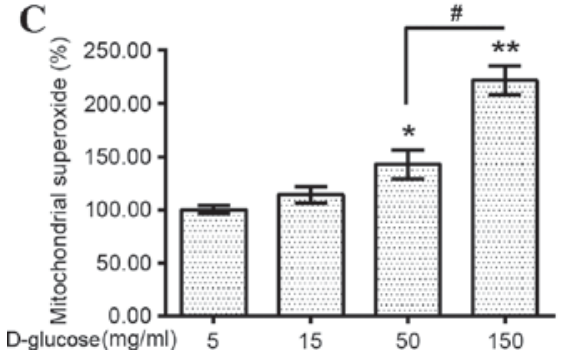

B

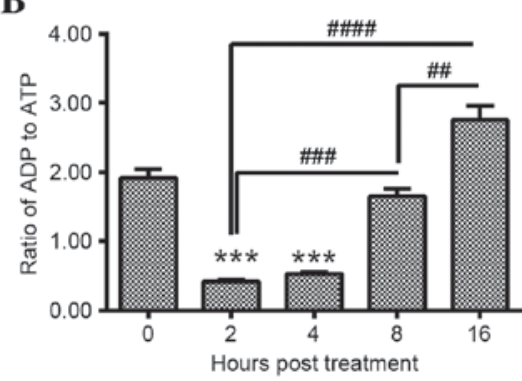

D

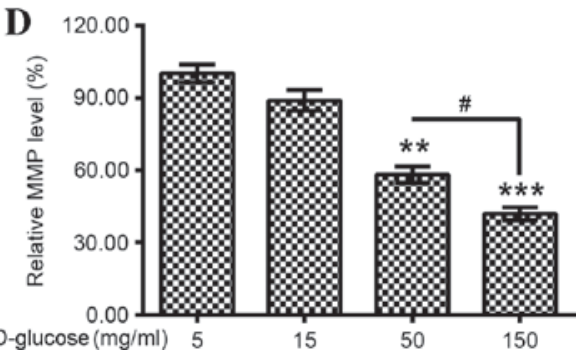

Figure 3. Hyperglycemia induces dose-dependent mitochondrial dysfunction in endothelial HUV-EC-C cells. (A) Mitochondrial size $\left({ }^{*} \mathrm{P}<0.05\right.$, ${ }^{* *} \mathrm{P}<0.01$ and ${ }^{* * *} \mathrm{P}<0.001$ vs. control), (B) ratio of ADP to ATP $\left({ }^{* * *} \mathrm{P}<0.001\right.$ vs. $0 \mathrm{~h} ;{ }^{\# \#} \mathrm{P}<0.01,{ }^{\# \# \#} \mathrm{P}<0.001$ and ${ }^{\# \# \# \#} \mathrm{P}<0.0001$ as indicated), (C) mitochondrial superoxide levels $\left({ }^{*} \mathrm{P}<0.05\right.$ and ${ }^{* *} \mathrm{P}<0.01$ vs. $5 \mathrm{mg} / \mathrm{ml} \mathrm{D}$-glucose; ${ }^{\#} \mathrm{P}<0.05$ as indicated) and (D) relative MMP levels $\left({ }^{* *} \mathrm{P}<0.01\right.$ and ${ }^{* * * *} \mathrm{P}<0.001$ vs. $5 \mathrm{mg} / \mathrm{ml} \mathrm{D}$-glucose; ${ }^{\#} \mathrm{P}<0.05$ as indicated) in D-glucose-treated HUV-EC-C cells. Data are presented as the mean \pm standard deviation of four independent experiments. ADP, adenosine disphosphate; ATP, adenosine trisphosphate; MMP, mitochondrial membrane potential.

at 1,2 and $4 \mathrm{~h}$ following treatment when compared with $0 \mathrm{~h}$ $(\mathrm{P}<0.01, \mathrm{P}<0.01$ and $\mathrm{P}<0.001$, respectively; Fig $2 \mathrm{~F})$. In addition, significantly increased levels of ROS were observed at $4 \mathrm{~h}$ following treatment compared with $1 \mathrm{~h}$ following treatment $(\mathrm{P}<0.05$; Fig. $2 \mathrm{~F})$, with decreased ROS generation at 6 and $8 \mathrm{~h}$ following treatment when compared with $4 \mathrm{~h}$ following treatment $(\mathrm{P}<0.05$ at $6 \mathrm{~h}$ vs. $4 \mathrm{~h}$; Fig. $2 \mathrm{~F})$. The ratio of ethidium to DHE peaked at $4 \mathrm{~h}$ following D-glucose treatment (Fig. 2F).

Hyperglycemia promotes mitochondrial dysfunction in $H U V-E C-C$ cells. To further investigate the effect of oxidative stress exerted by hyperglycemia in the HUV-EC-C cells, mitochondrial function was examined in D-glucose-treated HUV-EC-C cells. An assay that measured glucose-induced mitochondrial swelling was initially performed. Mitochondrial size significantly increased from 4-32 h following $50 \mathrm{mg} / \mathrm{ml}$ D-glucose treatment when compared with the $0 \mathrm{~h}$ time-point (4 h, $\mathrm{P}<0.05 ; 8$ h, $\mathrm{P}<0.01 ; 16$ h, $\mathrm{P}<0.001 ; 32$ h, $\mathrm{P}<0.01$; Fig. $3 \mathrm{~A}$ ), with mitochondrial swelling peaking at $16 \mathrm{~h}$ following $50 \mathrm{mg} / \mathrm{ml} \mathrm{D}$-glucose treatment. The ratio of ADP to ATP was then determined in the D-glucose-treated HUV-EC-C cells. The ADP:ATP ratio decreased significantly at 2 and $4 \mathrm{~h}$ following treatment when compared with the $0 \mathrm{~h}$ time-point $(\mathrm{P}<0.001$ and $\mathrm{P}<0.001$, respectively; Fig. $3 \mathrm{~B})$. However, a significant increase in the ADP: ATP ratio was observed at 8 and $16 \mathrm{~h}$ following treatment when compared with the $2 \mathrm{~h}$ time-point $(\mathrm{P}<0.001$ and $\mathrm{P}<0.0001$, respectively; Fig. 3B). This effect was time-dependent, with a significantly greater increase at $16 \mathrm{~h}$ following treatment when compared to $8 \mathrm{~h}$ $(\mathrm{P}<0.01$; Fig. 3B).

In addition, the mitochondrial localized superoxide and MMP were examined in D-glucose treated HUV-EC-C cells. Mitochondrial superoxide was significantly upregulated by 50 and $150 \mathrm{mg} / \mathrm{ml} \mathrm{D-glucose} \mathrm{treatment} \mathrm{compared} \mathrm{with}$
$5 \mathrm{mg} / \mathrm{ml} \mathrm{D}$-glucose-treated controls $(\mathrm{P}<0.05$ and $\mathrm{P}<0.01$, respectively; Fig. 3C). This effect was dose-dependent, with a significant increase in mitochondrial superoxide observed in HUV-EC-C cells treated with $150 \mathrm{mg} / \mathrm{ml} \mathrm{D-glucose}$ when compared with $50 \mathrm{mg} / \mathrm{ml}$ D-glucose $(\mathrm{P}<0.05$; Fig. $3 \mathrm{C})$. In addition, the MMP was significantly reduced by 50 and $150 \mathrm{mg} / \mathrm{ml} \mathrm{D}$-glucose treatment when compared with the controls $(\mathrm{P}<0.01$ and $\mathrm{P}<0.001$, respectively; Fig. 3D). This effect was dose-dependent, with a significantly greater reduction in MMP in $150 \mathrm{mg} / \mathrm{ml} \mathrm{D}$-glucose-treated cells when compared with $50 \mathrm{mg} / \mathrm{ml} \mathrm{D}$-glucose-treated cells $(\mathrm{P}<0.05$; Fig. 3D). These results suggest that hyperglycemia promotes mitochondrial dysfunction in HUV-EC-C cells.

Activation of SIRT1 inhibits hyperglycemia-induced mitochondrial dysfunction and apoptosis in HUV-EC-C cells. In order to investigate the involvement of SIRT1 in hyperglycemia-induced mitochondrial dysfunction and apoptosis in HUV-EC-C cells, the influence of hyperglycemia on SIRT1 expression and activity in HUV-EC-C cells exposed to high glucose was examined. SIRT1 activity was then manipulated with the SIRT1 activator (RSV) and inhibitor (sirtinol), and mitochondrial function and induction of apoptosis were examined in D-glucose-treated HUV-EC-C cells. SIRT1 mRNA expression levels were significantly decreased following 50 and $150 \mathrm{mg} / \mathrm{ml} \mathrm{D}$-glucose treatment when compared with the controls $(\mathrm{P}<0.05$ and $\mathrm{P}<0.01$, respectively; Fig. 4A). However, the western blotting assay demonstrated a significant increase in SIRT1 protein expression levels following $50 \mathrm{mg} / \mathrm{ml}$ D-glucose treatment when compared with controls $(\mathrm{P}<0.01$; Fig. 4B and C). In addition, SIRT1 activity was determined in $50 \mathrm{mg} / \mathrm{ml}$ D-glucose-treated and untreated HUV-EC-C cells. The results demonstrated thatSIRT1 activity was significantly downregulated in $50 \mathrm{mg} / \mathrm{ml}$ D-glucose-treated HUV-EC-C cells when 


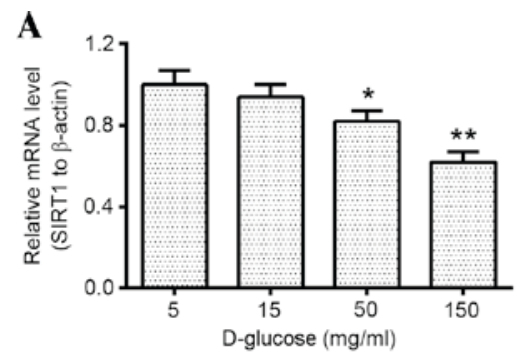

$\mathbf{B}$

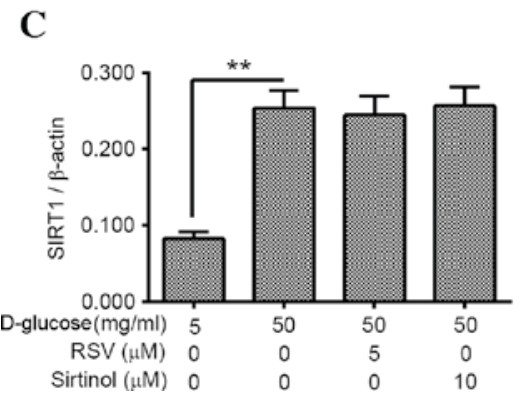

Figure 4. Hyperglycemia affects SIRT1 activity in HUV-EC-C cells. (A) Relative SIRT1 mRNA expression levels in D-glucose-treated HUV-EC-C cells $\left({ }^{*} \mathrm{P}<0.05\right.$ and ${ }^{* *} \mathrm{P}<0.01$ vs. $5 \mathrm{mg} / \mathrm{ml} \mathrm{D}$-glucose). (B) Western blotting assay results and (C) quantification of SIRT1 protein expression levels relative to $\beta$-actin $\left({ }^{* *} \mathrm{P}<0.01\right.$ as indicated). (D) SIRT1 activity in D-glucose-treated HUV-EC-C cells following treatment with RSV or sirtinol for $24 \mathrm{~h}\left({ }^{*} \mathrm{P}<0.05\right.$ and ${ }^{* * *} \mathrm{P}<0.01$ as indicated). SIRT1, sirtuin 1; RSV, resveratrol.

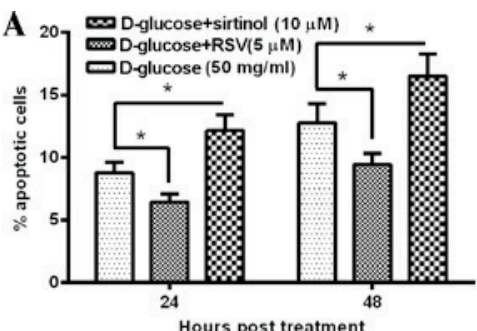

C
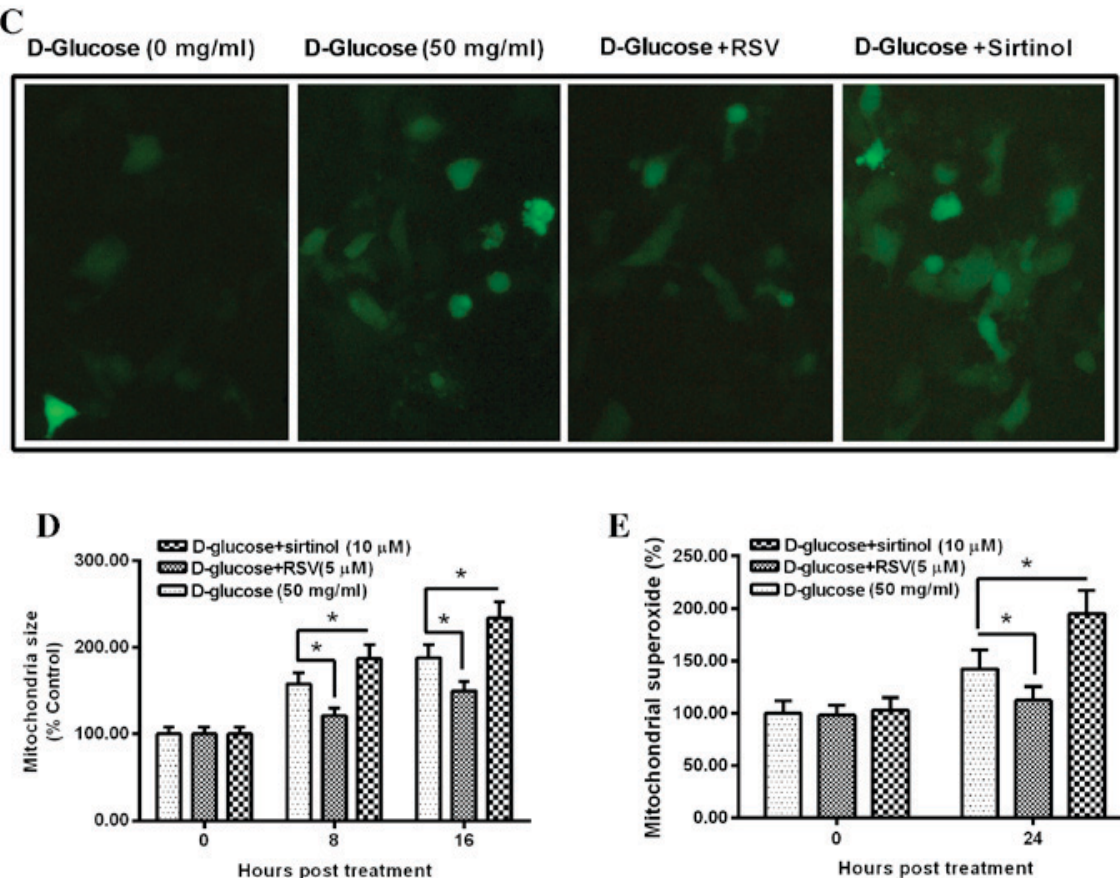

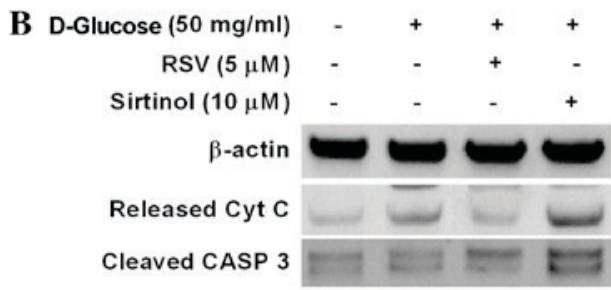

Lysed PARP
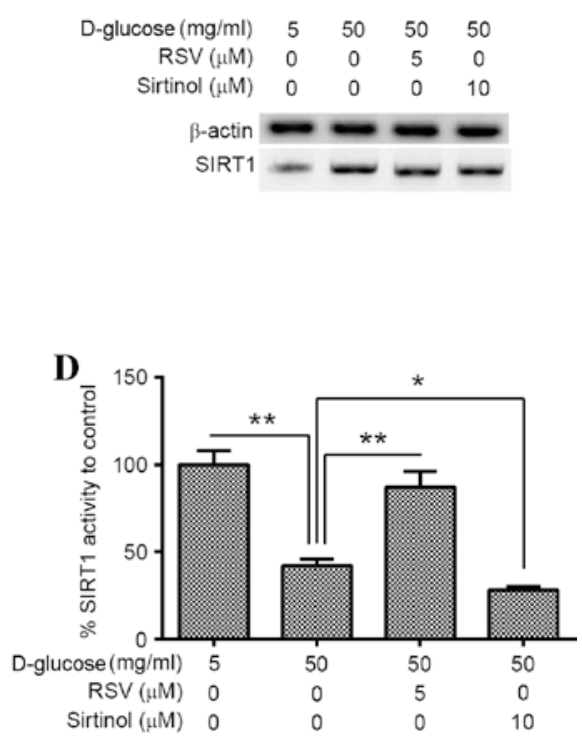

D 
compared with the controls ( $\mathrm{P}<0.01$; Fig. 4D). Although $5 \mu \mathrm{M}$ RSV or $10 \mu \mathrm{M}$ sirtinol treatment failed to alter SIRT1 protein expression levels in $50 \mathrm{mg} / \mathrm{ml}$ D-glucose-treated HUV-EC-C cells (Fig. 4B and C), SIRT1 activity was significantly increased following $50 \mathrm{mg} / \mathrm{ml}$ D-glucose plus $5 \mu \mathrm{M}$ RSV treatment when compared with $50 \mathrm{mg} / \mathrm{ml} \mathrm{D}$-glucose-only treated cells $(\mathrm{P}<0.01$; Fig. 4D), and significantly reduced in $50 \mathrm{mg} / \mathrm{ml} \mathrm{D}$-glucose plus $10 \mu \mathrm{M}$ sirtinol treated cells when compared with $50 \mathrm{mg} / \mathrm{ml}$ $\mathrm{D}$-glucose-only treated cells $(\mathrm{P}<0.05$; Fig. 4D).

Regulation of SIRT1 activity by RSV or sirtinol significantly inhibited and increased hyperglycemia-induced apoptosis and mitochondrial dysfunction, respectively. The percentage of apoptotic cells was significantly decreased in $50 \mathrm{mg} / \mathrm{ml} \mathrm{D}$-glucose plus $5 \mu \mathrm{M}$ RSV-treated HUV-EC-C cells when compared with $50 \mathrm{mg} / \mathrm{ml} \mathrm{D}$-glucose-only treated cells at 24 and $48 \mathrm{~h}$ following treatment $(\mathrm{P}<0.05$ and $\mathrm{P}<0.05$, respectively; Fig. 5A). By contrast, the percentage of apoptotic cells was significantly increased in $50 \mathrm{mg} / \mathrm{ml} \mathrm{D}$-glucose plus $10 \mu \mathrm{M}$ sirtinol-treated HUV-EC-C cells when compared with $50 \mathrm{mg} / \mathrm{ml} \mathrm{D}$-glucose-only treated cells at 24 and $48 \mathrm{~h}$ following treatment $(\mathrm{P}<0.05$ and $\mathrm{P}<0.05$, respectively; Fig. $5 \mathrm{~A})$. Western blotting assay results indicated that the protein levels of apoptosis-associated markers, including cytochrome c, cleaved caspase 3 and lyzed PARP, were markedly decreased following $50 \mathrm{mg} / \mathrm{ml} \mathrm{D}$-glucose plus $5 \mu \mathrm{M}$ RSV treatment and notably increased following $50 \mathrm{mg} / \mathrm{ml}$ D-glucose plus $10 \mu \mathrm{M}$ sirtinol treatment when compared with cells treated with $50 \mathrm{mg} / \mathrm{ml} \mathrm{D}$-glucose alone (Fig. 5B). Hyperglycemia-induced accumulation of ROS was reduced by $50 \mathrm{mg} / \mathrm{ml} \mathrm{D}$-glucose plus $5 \mu \mathrm{M}$ RSV treatment and increased by $50 \mathrm{mg} / \mathrm{ml}$ D-glucose plus $10 \mu \mathrm{M}$ sirtinol treatment when compared with cells treated with $50 \mathrm{mg} / \mathrm{ml}$ D-glucose alone (Fig. 5C). In addition, mitochondrial swelling was significantly inhibited by $50 \mathrm{mg} / \mathrm{ml} \mathrm{D}$-glucose plus $5 \mu \mathrm{M}$ RSV treatment, and significantly increased by $50 \mathrm{mg} / \mathrm{ml}$ D-glucose plus $10 \mu \mathrm{M}$ sirtinol treatment, when compared with cells treated with $50 \mathrm{mg} / \mathrm{ml}$ D-glucose only $(\mathrm{P}<0.05$ and $\mathrm{P}<0.05$, respectively; Fig. 5D). The production of mitochondrial localized superoxide was significantly decreased by $50 \mathrm{mg} / \mathrm{ml}$ D-glucose plus $5 \mu \mathrm{M} \mathrm{RSV}$ treatment, and significantly increased by $50 \mathrm{mg} / \mathrm{ml} \mathrm{D}$-glucose plus $10 \mu \mathrm{M}$ sirtinol treatment, when compared with cells treated with $50 \mathrm{mg} / \mathrm{ml} \mathrm{D}$-glucose only $(\mathrm{P}<0.05$ and $\mathrm{P}<0.05$, respectively; Fig. 5E). These results suggest that activation of SIRT1 prevents hyperglycemia-induced mitochondrial dysfunction and apoptosis in HUV-EC-C cells.

\section{Discussion}

DM-associated mitochondrial dysfunction has been demonstrated to be markedly upregulated by hyperglycemia in hepatocytes $(28,29)$, skeletal muscle cells $(30)$, cardiomyocytes $(31,32)$, retinal cells $(33)$ and in renal proximal tubular cells (34). Dysfunctional mitochondria are one of the two major sources of increased ROS production under hyperglycemic conditions (8-10). The results of the present study confirmed that hyperglycemia promotes oxidative stress and mitochondrial dysfunction in human endothelial HUV-EC-C cells. ROS accumulation, mitochondrial swelling, the ratio of ADP to ATP and the amount of mitochondrial localized superoxide were increased by treatment with $>50 \mathrm{mg} / \mathrm{ml} \mathrm{D}$-glucose. In addition, the MMP was significantly decreased by $>50 \mathrm{mg} / \mathrm{ml}$ D-glucose treatment. Taken together, these results confirm that hyperglycemia promoted oxidative stress and mitochondrial dysfunction in HUV-EC-C cells. Dysfunctional mitochondria have previously been demonstrated to induce apoptotic damage to hepatocytes $(28)$, cardiomyocytes $(31,32)$ and retinal cells (33). Consistent with these results, the present study confirmed that hyperglycemia induces apoptosis in HUV-EC-C cells, which suggests that hyperglycemia-induced oxidative stress and mitochondrial dysfunction may lead to apoptotic death of HUV-EC-C cells.

SIRT1 is the mammalian homolog of the yeast protein Sir2, and is thought to be involved in the regulation of aging (35). However, to the best of our knowledge, only limited data supports the regulatory involvement of SIRT1 in aging and longevity in mammals, although it has been confirmed as a key regulator of cellular senescence and metabolic pathways in response to nutrient status (35). SIRT1 is highly expressed in the vasculature during blood vessel growth (36). Notably, SIRT1 alleviates oxidative stress and mitochondrial dysfunction (24). Previous reports have demonstrated that the SIRT1 activator, RSV, attenuates high-fat diet-induced insulin resistance by influencing skeletal muscle lipid transport and ameliorating mitochondrial function (37). Despite the potential of SIRT1 agonists to alleviate oxidative stress and mitochondrial dysfunction, there remains a need to increase the specificity of SIRT1 in ameliorating endothelial function in the context of hyperglycemia. The results of the present study confirmed the prevention of hyperglycemia-induced apoptosis by RSV and the increase in hyperglycemia-induced apoptosis by sirtinol, via the amelioration or enhancement of oxidative stress and mitochondrial dysfunction in D-glucose-treated endothelial HUV-EC-C cells. The present study expands upon previous observations of SIRT1 involvement in hyperglycemia-induced oxidative stress and mitochondrial dysfunction in endothelial cells $(27,36)$, and the results suggest that manipulation of SIRT1 signaling may ameliorate oxidative stress-mediated injury to endothelial cells by hyperglycemia during vascular complications in either type I or type II diabetes.

In conclusion, the present study confirmed that oxidative stress, mitochondrial dysfunction and apoptosis are increased by hyperglycemia in human umbilical vein endothelial cells (HUV-EC-C). In addition, the results demonstrated that manipulation of SIRT1 activity using a SIRT1 activator (RSV), or a SIRT1 inhibitor (sirtinol), ameliorated or enhanced hyperglycemia-induced mitochondrial dysfunction and apoptosis in HUV-EC-C cells, respectively. The results confirm the protective effects of SIRT1 against the hyperglycemia-induced apoptosis potentially via the alleviation of mitochondrial dysfunction and oxidative stress.

\section{References}

1. Chen F, Qian LH, Deng B, Liu ZM, Zhao Y and Le YY: Resveratrol protects vascular endothelial cells from high glucose-induced apoptosis through inhibition of NADPH oxidase activation-driven oxidative stress. CNS Neurosci Ther 19: 675-681, 2013.

2. Wang XM, Yao M, Liu SX, Hao J, Liu QJ and Gao F: Interplay between the Notch and PI3K/Akt pathways in high glucose-induced podocyte apoptosis. Am J Physiol Renal Physiol 306: F205-F213, 2014. 
3. Muto T, Tien T, Kim D, Sarthy VP and Roy S: High glucose alters $\mathrm{Cx} 43$ expression and gap junction intercellular communication in retinal Müller cells: Promotes Müller cell and pericyte apoptosis. Invest Ophthalmol Vis Sci 55: 4327-4337, 2014.

4. Pan Y, Wang Y, Zhao Y, Peng K, Li W, Wang Y, Zhang J, Zhou S, Liu Q, Li X, et al: Inhibition of JNK phosphorylation by a novel curcumin analog prevents high glucose-induced inflammation and apoptosis in cardiomyocytes and the development of diabetic cardiomyopathy. Diabetes 63: 3497-3511, 2014.

5. Cave AC, Brewer AC, Narayanapanicker A, Ray R, Grieve DJ, Walker S and Shah AM: NADPH oxidases in cardiovascular health and disease. Antioxid Redox Signal 8: 691-728, 2006.

6. Du XL, Edelstein D, Rossetti L, Fantus IG, Goldberg H, Ziyadeh F, Wu J and Brownlee M: Hyperglycemia-induced mitochondrial superoxide overproduction activates the hexosamine pathway and induces plasminogen activator inhibitor-1 expression by increasing Sp1 glycosylation. Proc Natl Acad Sci USA 97: 12222-12226, 2000.

7. Nishikawa T, Edelstein D, Du XL, Yamagishi S, Matsumura T, Kaneda Y, Yorek MA, Beebe D, Oates PJ, Hammes HP, et al: Normalizing mitochondrial superoxide production blocks three pathways of hyperglycaemic damage. Nature 404: 787-790, 2000

8. Zhang WF, Xu YY, Xu KP, Wu WH, Tan GS, Li YJ and Hu CP: Inhibitory effect of selaginellin on high glucose-induced apoptosis in differentiated PC12 cells: Role of NADPH oxidase and LOX-1. Eur J Pharmacol 694: 60-68, 2012.

9. Sachse A and Wolf G: Angiotensin II-induced reactive oxygen species and the kidney. J Am Soc Nephrol 18: 2439-2446, 2007.

10. Coppey LJ, Davidson EP, Rinehart TW, Gellett JS, Oltman CL, Lund DD and Yorek MA: ACE inhibitor or angiotensin II receptor antagonist attenuates diabetic neuropathy in streptozotocin-induced diabetic rats. Diabetes 55: 341-348, 2006.

11. Hammes HP, Martin S, Federlin K, Geisen K and Brownlee M: Aminoguanidine treatment inhibits the development of experimental diabetic retinopathy. Proc Natl Acad Sci USA 88: 11555-11558, 1991.

12. Du Y, Miller CM and Kern TS: Hyperglycemia increases mitochondrial superoxide in retina and retinal cells. Free Radic Biol Med 35: 1491-1499, 2003.

13. Xia P, Inoguchi T, Kern TS, Engerman RL, Oates PJ and King GL: Characterization of the mechanism for the chronic activation of diacylglycerol-protein kinase $C$ pathway in diabetes and hypergalactosemia. Diabetes 43: 1122-1129, 1994.

14. Koya D and King GL: Protein kinase C activation and the development of diabetic complications. Diabetes 47: 859-866, 1998.

15. Nerlich AG, Sauer U, Kolm-Litty V, Wagner E, Koch M and Schleicher ED: Expression of glutamine:fructose-6-phosphate amidotransferase in human tissues: Evidence for high variability and distinct regulation in diabetes. Diabetes 47: 170-178, 1998.

16. Perez-Matute P, Zulet MA and Martinez JA: Reactive species and diabetes: Counteracting oxidative stress to improve health. Curr Opin Pharmacol 9: 771-779, 2009.

17. Qin X, Zhang Z, Xu H and $\mathrm{Wu} \mathrm{Y}$ : Notch signaling protects retina from nuclear factor- $\kappa \mathrm{B}$ - and poly-ADP-ribose-polymerasemediated apoptosis under high-glucose stimulation. Acta Biochim Biophys Sin (Shanghai) 43: 703-711, 2011.

18. Zhang Q and Steinle JJ: DNA-PK phosphorylation of IGFBP-3 is required to prevent apoptosis in retinal endothelial cells cultured in high glucose. Invest Ophthalmol Vis Sci 54: 3052-3057, 2013.

19. He M, Nitti M, Piras S, Furfaro AL, Traverso N, Pronzato MA and Mann GE: Heme oxygenase-1-derived bilirubin protects endothelial cells against high glucose-induced damage. Free Radic Biol Med 89: 91-98, 2015.

20. He S, Zhang J, Qi X, Wang D, Wang X and Zhou S: Neuregulin protects human umbilical vein endothelial cell via activating CD98hc through MAPK pathway. Int J Clin Exp Med 8: 6702-6712, 2015 .

21. Zhang Y, Liu J, Luo JY, Tian XY, Cheang WS, Xu J, Lau CW, Wang L, Wong WT, Wong CM, et al: Upregulation of angiotensin (1-7)-mediated signaling preserves endothelial function through reducing oxidative stress in diabetes. Antioxid Redox Signal 23 : $880-892,2015$
22. Wang R, Lu L, Guo Y, Lin F, Chen H, Chen W and Chen M Effect of glucagon-like peptide-1 on high-glucose-induced oxidative stress and cell apoptosis in human endothelial cells and its underlying mechanism. J Cardiovasc Pharmacol 66: 135-140, 2015.

23. Chen YR, Lai YL, Lin SD, Li XT, Fu YC and Xu WC: SIRT1 interacts with metabolic transcriptional factors in the pancreas of insulin-resistant and calorie-restricted rats. Mol Biol Rep 40: 3373-3380, 2013

24. Gerhart-Hines Z, Rodgers JT, Bare O, Lerin C, Kim SH, Mostoslavsky R, Alt FW, Wu Z and Puigserver P: Metabolic control of muscle mitochondrial function and fatty acid oxidation through SIRT1/PGC-1alpha. EMBO J 26: 1913-1923, 2007.

25. Schmittgen TD and Livak KJ: Analyzing real-time PCR data by the comparative C(T) method. Nat Protoc 3: 1101-1108, 2008

26. Duan J, Wei G, Guo C, Cui J, Yan J, Yin Y, Guan Y, Weng Y, $\mathrm{Zhu} \mathrm{Y}, \mathrm{Wu} \mathrm{X}$, et al: Aralia taibaiensis protects cardiac myocytes against high glucose-induced oxidative stress and apoptosis. Am J Chin Med 43: 1159-1175, 2015.

27. Zhao H, Ma T, Fan B, Yang L, Han C, Luo J and Kong L: Protective effect of trans- $\delta$-viniferin against high glucose-induced oxidative stress in human umbilical vein endothelial cells through the SIRT1 pathway. Free Radic Res 50: 68-83, 2016.

28. Jiang $X$, Tang $X$, Zhang $P$, Liu $G$ and Guo $H$ : Cyanidin-3-O- $\beta$-glucoside protects primary mouse hepatocytes against high glucose-induced apoptosis by modulating mitochondrial dysfunction and the PI3K/Akt pathway. Biochem Pharmacol 90: 135-144, 2014.

29. Xu Z, Zhang L, Li X, Jiang Z, Sun L, Zhao G, Zhou G, Zhang H, Shang $J$ and Wang T: Mitochondrial fusion/fission process involved in the improvement of catalpol on high glucose-induced hepatic mitochondrial dysfunction. Acta Biochim Biophys Sin (Shanghai) 47: 730-740, 2015.

30. Zhang HH, Ma XJ, Wu LN, Zhao YY, Zhang PY, Zhang YH, Shao MW, Liu F, Li F and Qin GJ: SIRT1 attenuates high glucose-induced insulin resistance via reducing mitochondrial dysfunction in skeletal muscle cells. Exp Biol Med (Maywood) 240: 557-565, 2015.

31. Zhang M, Niu X,Hu J, Yuan Y, Sun S, Wang J, Yu W, Wang C, Sun D and Wang H: Lin28a protects against hypoxia/reoxygenation induced cardiomyocytes apoptosis by alleviating mitochondrial dysfunction under high glucose/high fat conditions. PLoS One 9: e110580, 2014

32. Huang $\mathrm{H}$, Wu K, You Q, Huang R, Li S and Wu K: Naringin inhibits high glucose-induced cardiomyocyte apoptosis by attenuating mitochondrial dysfunction and modulating the activation of the p38 signaling pathway. Int J Mol Med 32: 396-402, 2013.

33. Roy S, Trudeau K, Roy S, Tien T and Barrette KF: Mitochondrial dysfunction and endoplasmic reticulum stress in diabetic retinopathy: Mechanistic insights into high glucose-induced retinal cell death. Curr Clin Pharmacol 8: 278-284, 2013.

34. Munusamy S and MacMillan-Crow LA: Mitochondrial superoxide plays a crucial role in the development of mitochondrial dysfunction during high glucose exposure in rat renal proximal tubular cells. Free Radic Biol Med 46: 1149-1157, 2009.

35. Bordone L and Guarente L: Calorie restriction, SIRT1 and metabolism: Understanding longevity. Nat Rev Mol Cell Biol 6: 298-305, 2005.

36. Potente M, Ghaeni L, Baldessari D, Mostoslavsky R, Rossig L, Dequiedt F, Haendeler J, Mione M, Dejana E, Alt FW, et al: SIRT1 controls endothelial angiogenic functions during vascular growth. Genes Dev 21: 2644-2658, 2007.

37. Chen LL, Zhang HH, Zheng J, Hu X, Kong W, Hu D, Wang SX and Zhang P: Resveratrol attenuates high-fat diet-induced insulin resistance by influencing skeletal muscle lipid transport and subsarcolemmal mitochondrial $\beta$-oxidation. Metabolism 60: 1598-1609, 2011. 